\title{
Avomaankurkku hyötyy tihkukastelusta
}

\author{
Terhi Suojala ${ }^{1)}$, Tapio Salo ${ }^{2)}$ ja Janne Pulkkinen ${ }^{3)}$ \\ ${ }^{1)}$ MTT, Kasvintuotannon tutkimus, Puutarhatuotanto, Toivonlinnantie 518, 21500 Piikkiö, \\ terhi.suojala@mtt.fi \\ ${ }^{2)}$ MTT, Ympäristöntutkimus, Maaperä ja ympäristö, 31600 Jokioinen, tapio.salo@mtt.fi \\ ${ }^{3)}$ Kemira GrowHow, PL 900,00181 Helsinki, janne.pulkkinen@kemira-growhow.com
}

\begin{abstract}
Johdanto
Avomaankurkkua viljellään Suomessa pääosin sopimusviljelynä säilykkeitä valmistavalle teollisuudelle. Viljelyn ongelmina ovat olleet vuotuiset satovaihtelut ja epätasainen laatu. Sadon määrän, laadun ja viljelyvarmuuden parantamiseksi alettiin vuonna 2000 tutkia tarkennetun kastelun ja lannoituksen mahdollisuuksia. Esitutkimuksessa vuonna 2000 selvitettiin tihkukastelun ja siihen liitetyn kastelulannoituksen vaikutuksia kurkun kasvuun ja satoon verrattuna perinteiseen päältäkasteluun ja lannoitteiden hajalevitykseen. Sateisena kesänä tihkukastelusta saatujen myönteisten kokemusten innostamana aloitettiin vuonna 2001 laaja kolmivuotinen tutkimushanke, jossa tavoitteena on tarkentaa avomaankurkun, mansikan, mustaherukan ja vadelman kastelu- ja lannoitusohjelmia tihkukastelumenetelmää hyödyntäen. Tutkimuksen kenttäkokeet on toteutettu MTT puutarhatuotannossa Piikkiössä. Hankkeeseen sisältyy myös MTT:n taloustutkimuksen johtama osa tihkukastelun talousvaikutuksista ja Työtehoseuran eri kastelumenetelmien työnkäyttöä selvittävä osa.

Tässä esityksessä kuvataan avomaankurkun kastelu- ja lannoitusohjelmia koskevan osan toteutus ja tulokset. Kurkkukokeiden tavoitteena oli selvittää, miten erilaiset kastelumäärät vaikuttavat avomaankurkun kasvuun ja sadontuottoon, ja kehittää avomaankurkulle sopiva lannoitusohjelma, jossa hyödynnetään kastelulannoitusta.
\end{abstract}

\section{Aineisto ja menetelmät}

Avomaankurkkukokeet toteutettiin MTT:ssä Piikkiössä vuosina 2001-2003. Jokaisena vuonna järjestettiin kaksi koetta, joista toisessa tutkittiin kastelumäärien vaikutusta ja toisessa vertailtiin erilaisia lannoitusohjelmia. Koekentän maalaji oli kahtena ensimmäisenä koevuonna multava karkea hieta ja viimeisenä koevuonna runsasmultainen hietasavi.

Kastelukoe toteutettiin kevytrakenteisessa muovihuoneessa, jonka sivut olivat auki noin $80 \mathrm{~cm}: n$ korkeudelle ja päädyt kokonaan auki. Muovihuoneen tarkoitus oli estää sadeveden pääsy taimien juuristoalueelle, jotta voitiin ylläpitää halutut maan kosteuskäsittelyt. Koejärjestelyt olivat joka vuosi samanlaiset. Maan kosteutta mitattiin 20 ja $40 \mathrm{~cm}: n$ syvyyksiin upotetuilla tensiometreillä. Kokeessa verrattiin kolmea maan kosteuden arvoa $(-150,-300 \mathrm{ja}-600 \mathrm{hPa})$, joita käytettiin raja-arvoina kastelun aloittamiseen. Kastelu aloitettiin tensiometrien osoittaessa maan kuivuneen kastelurajalle, ja maan kosteus pyrittiin palauttamaan kenttäkapasiteettiin. Eri raja-arvoja käytettäessä kastelumäärät vaihtelivat varsin paljon. Maan kosteustilan ja kastelumäärien vaikutusta mitattiin seuraamalla kasvien kasvua (lehtien, sivuversojen ja kukkien määrä tainta kohti) sekä mittaamalla eri käsittelyiden tuottama sato. Lisäksi vuonna 2003 mitattiin kurkkujen kiinteyttä Lloyd-aineenkoetuslaitteella.

Lannoituskokeessa vertailtavat käsittelyt muodostuivat erilaisista peruslannoitusten ja kastelulannoitusohjelmien yhdistelminä. Käsittelyt muuttuivat hieman koevuosien välillä tulosten ohjaamina, mutta osa käsittelyistä pysyi aina samana. Ensimmäisenä koevuonna tutkittiin runsaasti fosforia sisältävän starttilannoituksen vaikutusta, verrattiin kastelulannoituksessa moniravinteisten kastelulannoitteiden käyttöä pelkästään typpeä ja kaliumia sisältäviin lannoitteisiin sekä tutkittiin kastelulannoitusmäärän lisäämisen vaikutusta. Toisena koevuonna verrattiin edelleen moniravinteisia kastelulannoitteita typpi- ja kaliumlannoitteisiin ja tutkittiin kastelulannoitusmäärän lisäämisen vaikutusta. Lisäksi selvitettiin, voidaanko peruslannoitusmäärää vähentää sadon kärsimättä. Kolmantena koevuonna painotettiin entistä enemmän typpilannoitusmäärän tarkentamista ja verrattiin erilaisia typpimääriä kastelulannoituksessa sekä niiden jakoa perus- ja kastelulannoituksen välillä. Lisäksi tutkittiin, onko hyötyä lisätä kaliumin määrää kastelulannoituksessa.

Lannoituskokeessa seurattiin käsittelyiden vaikutusta kasvien kasvuun kuten kastelukokeessa. Lisäksi mitattiin kasvin vegetatiivisten osien massa neljä kertaa kasvukaudella ja poimittiin ja lajiteltiin sato kahdesti viikossa. Kasvien ravinteiden otto mitattiin kasvustonäytteistä tehtyjen ravinneanalyysien pohjalta. Maan ravinnetilaa seurattiin läpi kesän, ja viljelyn päätyttyä määritettiin liukoisen typen määrät 
myös syvemmistä maakerroksista.

Kaikissa kokeissa käytettiin Carine-lajiketta. Taimia esikasvatettiin kasvihuoneessa runsaan kahden viikon ajan ja istutettiin avomaalle touko-kesäkuun vaihteessa.

\section{Tulokset ja tulosten tarkastelu}

Kastelukokeessa runsaampi kastelu (kastelun aloituksen raja-arvo - $150 \mathrm{hPa}$ ) lisäsi lehtien ja sivuversojen muodostumista jonkin verran verrattuna kuivempana pidettyihin käsittelyihin, mutta vaikutus ei ollut joka vuosi tilastollisesti merkitsevä. Myöskään vaikutus satoon ei ollut tilastollisen analyysin mukaan merkitsevä joka vuosi, mutta suuntaus oli aina se, että maan pitäminen kosteampana lisäsi satoa jonkin verran (Taulukko 1). Kuivimpana pidettyyn käsittelyyn verrattuna sadonlisä kosteimmassa käsittelyssä oli 5-20 $\%$. Kurkkujen ulkoiseen laatuun tai vuonna 2003 mitattuun hedelmien kiinteyteen kastelukäsittelyt eivät vaikuttaneet.

Kokeessa maa on pysynyt yhtä kosteana kaikissa käsittelyissä lähes kesäkuun loppuun asti kevätkosteuden turvin, joten alkukesän kosteustilan merkitystä ei ole voitu selvittää. Todennäköisesti juuri istutusta seuraavien viikkojen veden saanti on erityisen oleellinen, jotta kasvit pääsevät nopeasti kasvuun ja lehtipinta-ala kehittyy suureksi ennen satokauden alkua.

Lannoituskokeissa pian istutuksen jälkeen annetusta starttilannoituksesta ei ollut mitattavaa hyötyä. Kastelulannoituksessa ei ollut etua kalliimpien moniravinteisten lannoitteiden käytöstä verrattuna pelkän typen ja kaliumin lisäämiseen. Kastelulannoitusmäärän ja erityisesti typpilannoitusmäärän lisääminen "normaalitasosta" sato-odotusten ja säätilan ollessa suotuisat lisäsi satoa noin $5 \%$, mutta vaikutus ei yleensä ollut tilastollisesti merkitsevä.

Sadon mukana on poistunut pellolta typpeä $90-110 \mathrm{~kg} / \mathrm{ha}$, fosforia $20-25 \mathrm{~kg} / \mathrm{ha}$ ja kaliumia $150-160$ $\mathrm{kg} / \mathrm{ha}$. Vegetatiivisissa kasvinosissa on mitattu kasvuston ollessa rehevimmillään elokuun alussa typpeä 40-70 kg/ha, fosforia 7-12 kg/ha ja kaliumia $90-150 \mathrm{~kg} / \mathrm{ha}$. Kasvien ravinteiden otto ei suoraan ole näiden määrien summa, sillä osa versojen ravinteista siirtynee hedelmiin satokauden lopulla. Avomaankurkku on tehokas ravinteiden ottaja, ja typen ja kaliumin kokonaisotto on ollut selvästi lannoitteissa annettuja määriä suurempi ja fosforin otto likimain lannoitefosforin määrän suuruinen.

\section{Johtopäätökset}

Tulosten mukaan tihkukastelumenetelmä sopii avomaankurkulle hyvin, sillä se mahdollistaa kasvualustan tasaisen kosteuden ylläpidon ja mahdollistaa ravinteiden lisäämisen satokaudella tarpeen mukaan. Kokeissa on varsin niukalla lannoituksella saatu hyvä sato ja erittäin hyvä lannoitteiden hyötysuhde.

Tasainen maan kosteus (kasteluraja -150 - -300 hPa) edistää versojen kasvua ja lisää satoa 5-20 \% verrattuna kuivempaa maahan. Sopiva raja-arvo kastelun aloittamiseen lienee noin 150-200 hPa, kun maan kosteutta mitataan tensiometreillä $20 \mathrm{~cm}: n$ syvyydessä. Kertakasteluaika ei saa olla yli 2-3 tuntia, jotta ravinteet eivät huuhtoudu juurten ulottumattomiin.

Lannoituskokeiden tulosten perusteella avomaankurkun lannoitukseen voi suositella ohjelmaa, jossa peruslannoituksessa ennen istutusta annetaan 1/3-1/2 kesän aikana tarvittavasta typestä ja kaliumista ja muut ravinteet koko kasvukautta varten. Kastelulannoituksessa riittää typen ja kaliumin lisääminen. Peruslannoituksella tuotetaan pääosa versostosta. Kastelulannoitus on hyvä aloittaa hieman ennen satokauden alkua. Useimpina vuosina sopiva kokonaistypen määrä on $120-140 \mathrm{~kg} / \mathrm{ha}$. Nopean sadontuoton vuosina typpimäärää voi lisätä, mutta odotettavissa oleva sadonlisä on vain noin $5 \%$.

Taulukko 1. Kastelumäärät ja avomaankurkun sato eri kastelurajoja käytettäessä vuosina 2001-2002. Suluissa sadonlisä prosentteina verrattuna kuivimpana pidettyyn käsittelyyn (kasteluraja $-600 \mathrm{hPa}$ ).

\begin{tabular}{lllllll}
\hline & 2001 & & 2002 & & 2003 \\
Kasteluraja & Kastelu & Sato & Kastelu & Sato & Kastelu & Sato \\
$h P a$ & $l / r m$ & $\mathrm{~kg} /$ ruutu & $\mathrm{l} / \mathrm{rm}$ & $\mathrm{kg} / \mathrm{ruutu}$ & $\mathrm{l} / \mathrm{rm}$ & $\mathrm{kg} / \mathrm{ruutu}$ \\
\hline-150 & 340 & $60,1(+12 \%)$ & 226 & $71,1(+5 \%)$ & 349 & $48,0(+20 \%)$ \\
-300 & 301 & $58,1(+8 \%)$ & 147 & $67,6(+0,3 \%)$ & 264 & $45,1(+12 \%)$ \\
-600 & 199 & 53,8 & 101 & 67,4 & 152 & 43,3
\end{tabular}

